\title{
ASSESSING THE ENVIROMENTAL EXTERNALITIES OF EXCESSIVE GROUNDWATER WITHDRAWALS USING THE CHOICE EXPERIMENT METHOD - A CASE STUDY OF KERMAN, IRAN
}

\author{
BANIASAdI, M. ${ }^{1,2}$-ZARE MEHRJORDI, M. R. ${ }^{1 *}$ - MEHRABI Boshrababdi, H. ${ }^{1}$-MirZAEI, H. R. ${ }^{1}-$ \\ REZAEI ESTAKHROOYE, A. ${ }^{3}$ \\ ${ }^{I}$ Department of Agricultural Economics, Shahid Bahonar University of Kerman \\ Research Square, Kerman, Iran \\ (phone: +98-34-3132-2606) \\ ${ }^{2}$ Young Researches Society, Shahid Bahonar University of Kerman \\ Research Square, Kerman, Iran \\ ${ }^{3}$ Department of Water Engineering, Shahid Bahonar University of Kerman \\ Researches Square, Kerman, Iran \\ *Corresponding author \\ e-mail:zare@uk.ac.ir \\ (Received $15^{\text {th }}$ Jun 2016; accepted $12^{\text {th }}$ Oct 2016)
}

\begin{abstract}
The main sources of water supply in the Kerman province of Iran are groundwater resources. In recent years, the over-exploitation of groundwater has decreased the water table and created environmental externalities. The reduction of groundwater reserves, reduction of vegetation, loss of plant and animal diversity, soil erosion and an increase in the potential for flooding in the area are some of the adverse environmental externalities. The aim of this study is to evaluate the externalities caused by the excessive withdrawals of groundwater from the Orzooiyeh plain in the Kerman province in Iran. In order to do this, the preferences of the people in this area were studied and the values of the residents' willingness to pay to improve the environmental attributes of the Orzooiyeh plain was extracted using the choice experiment method and conditional logit model. The results showed that the mean figure of the total households' WTP for the restoration and protection of the groundwater resources in order for it to return to the situation before the onset of externality, was 148259.1 USD annually. The results provided an argument in the debate on the new policy recommendation for groundwater withdrawals and helped to promote the ecosystem services of groundwater resources.
\end{abstract}

Keywords: CE approach; conditional logit; ecosystem; natural resources; Orzooiyeh plain

\section{Introduction}

The rapid growth of the world's population and agricultural development in the past decades, as well as the inadequate levels of surface water for human needs, have led to increased pumping water; this has resulted in the decline of groundwater levels and the depletion of aquifers (Kaiser and Skiller, 2003). Currently, Iran is one of the most groundwater resource-rich countries in the world (Doll et al., 2014); however, it is estimated that Iranian beneficiaries have extracted most of the groundwater reserves. According to the reports from the Ministry of Energy, as well as case studies, the lack of groundwater has become critical in some parts of Iran (Izady et al., 2012). Due to the lack of adequate access to surface water, the agricultural sector consumes large quantities of groundwater. Today, groundwater satisfies $55 \%$ of the total water demand in Iran, while the agricultural sector consumes more than $90 \%$ of groundwater (Madani, 2014). It is difficult to estimate the 
excessive extraction of groundwater, but a significant reduction in the level of groundwater table (up to 2 meters per year in some parts of the country) indicates the extent of the consumption of non-renewable areas of groundwater. Therefore, 277 of the 609 lowland plains in Iran are in a critical condition (Forootan et al., 2014; Joodaki et al., 2014). Excessive withdrawals of groundwater in Iran's agricultural sector will have economic and environmental externalities. Today, the depletion of groundwater reserves and its consequences, including increased costs of water exploitation, land subsidence and water quality decline, have become a global problem in many countries, including the US, Italy, Japan, Britain, China, Thailand, Taiwan and Mexico (Kaiser and Skiller, 2003). Groundwater is part of those renewable natural resources that, with reasonable and balanced exploitation, results in a sustainable use; however, not respecting their balanced exploitation leads to the destruction of these resources (Gayarti and Barbier, 2000). Excessive extraction of groundwater affects the quality, quantity and location of water; as a result, it affects the consumers and the environment (Lindgren, 1999) The results of these effects over time include rising costs of deep wells and water salinization due to the decrease in water levels (Lindgren, 1999). This causes an increase in the financial expenses involved in groundwater withdrawal, both in terms of investment, including the costs of drilling, tubing, pumping, and motor, as well as in terms of the operation, which requires more energy for pumping a certain volume of water (increase in variable costs of pumping water due to increased depth of wells). Therefore, it reduces the income from agriculture, decreases the price of agricultural land and increases the risk of salinity (Lindgren, 1999). Also, excessive withdrawal of groundwater resources reduces the quality of water resources as well as increases the risk of pollution of groundwater resources, both of which have an adverse effect on human health (Dibi, 2012). These externalities are more severe in countries like Iran, which is located in one of the most arid regions of the world and suffers from water scarcity and drought. In Iran, the Kerman province is the driest area and water resources are facing a serious crisis. In many studies, a reduction in the level of water in underground aquifers in the Kerman province has been mentioned. Due to the dry weather, drought, low annual rainfall and uncontrolled exploitation of aquifers, the reduction of water resources in the province has become a serious crisis. A reduction in the levels of aquifers is followed by many environmental problems, such as a reduction of water in wells, destruction of groundwater sources, loss of plant and animal diversity, water quality degradation, loss of vegetation and, consequently, soil erosion and an increase in the potential of flooding. Since a village economy is based on agriculture and agriculture, it is also dependent on water; therefore, this reduction in water quality and quantity, as well as the environmental consequences resulting from it, affect the welfare of farmers and all those people living within the region (TaghiZadeh and Soltani, 2013). Assessment of the environmental externalities to determine the external costs and environmental services caused by agriculture and excessive groundwater withdrawal is essential and provides the necessary information for decision-makers in order to manage it. There are many studies on environmental externalities and their assessment (Wei et al., 2010), most of which focus on the natural resources rather than agricultural systems. However, only a handful of studies have investigated the environmental externalities of agriculture (Environment Agency, 2007; EFTEC/IEEP, 2004; Lv et al., 2010; Wei et al., 2010). There are no frameworks or standard procedures for the evaluation, so that the results of the different studies cannot easily be compared with each other (Pretty et al., 2000). The role of individual preferences for ecosystem services of groundwater in residential areas and for farmers is infrequently discussed in the literature on the evaluation of the externalities of groundwater excessive extraction. To the best of the authors' knowledge, this is the first 
application of a choice experiment (CE) model to local choice modeling in the literature on the evaluation of externalities of groundwater excessive extraction. By applying CE method, this paper provides new evidence on the preferences of those people living in the area, as well as farmers, on the destruction of the ecosystem services (environmental externalities) due to groundwater excessive extraction by the local farmers. The aim of this study is to assess the environmental damages caused by excessive groundwater withdrawal of the Orzooiyeh plain, located in the Kerman province in Iran, and an estimation of the monetary value of the negative environmental externalities.

\section{Materials and methods}

\section{Study area}

Orzooiyeh plain is located between $55^{\circ} 48^{\prime}$ to $56^{\circ} 59^{\prime}$ Eastern longitude and $28^{\circ} 08^{\prime}$ to $28^{\circ} 59^{\prime}$ Northern latitude and at a distance of about $270 \mathrm{~km}$ from the center of Kerman province, in the South East of Iran. It is one of the major areas for producing crops, such as wheat, corn and vegetables due to its weather and soil conditions. Unfortunately, due to the growing exploitation of groundwater in the region, together with the continuing drought, its groundwater level has significantly declined. According to the information obtained in 1999, the balance of the Orzooiyeh plain was (-79) million cubic meters (KRWA, 2014). In addition, during the last 10 years, the balance of Orzooiyeh plain has always been negative and the water level decline in the plain saw an annual average of 1.78 meters (KRWA, 2014). According to available statistics, more than 82 per cent of withdrawals of groundwater in the plain are related to agriculture and crop production (KRWA, 2014). Excessive extraction in the agricultural sector has led to a sharp drop in water levels, as well as an abundance of economic and environmental damages to the region. The geographical location of Orzooiyeh plain is shown in Figure 1.

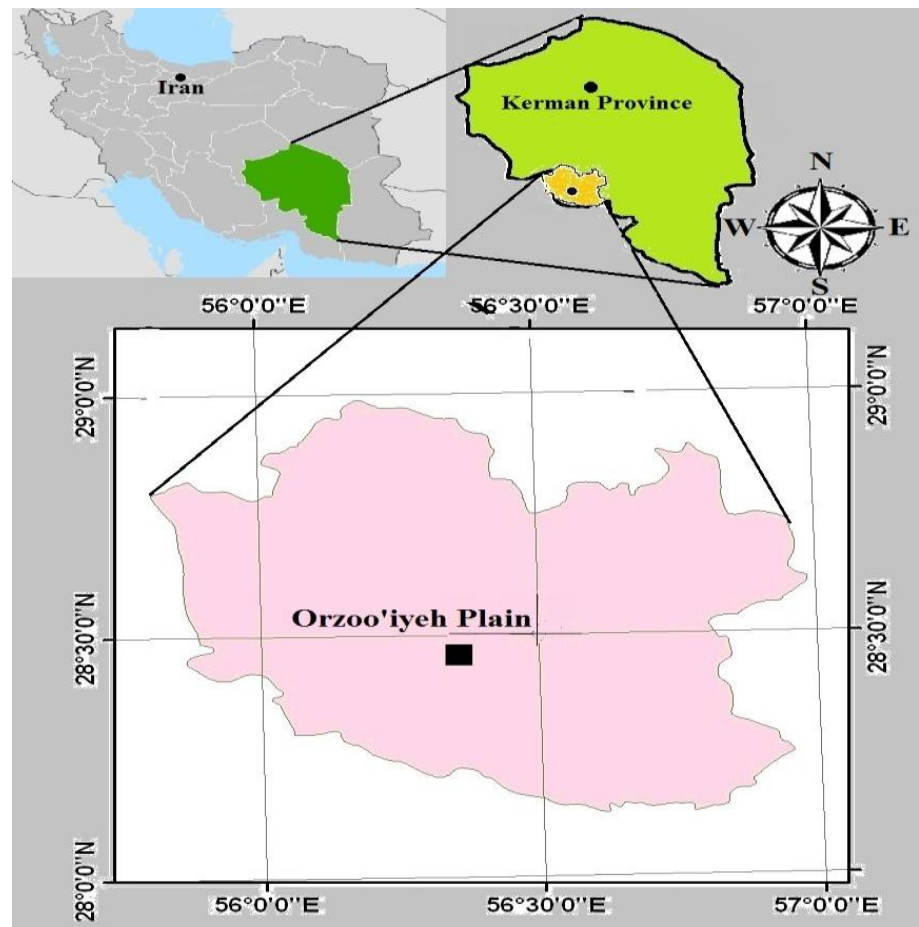

Figure 1. Geographical location of Orzooiyeh plain 


\section{Choice experiment approach}

According to neoclassical economic theory, market prices are usually an adequate reference for the value that society places on goods and services (Vega and Alpizar, 2011). However, for environmental goods and services, due to the market failures, prices do not exist and the value that people attach to them is not easily visible (Hanley et al., 1998). In this study, the CE method was used for the evaluation of non-market environmental externalities associated with the excessive withdrawal of groundwater from the Orzooiyeh plain of Kerman. In this plan, it is assumed that the continuation of the current trend of excessive extraction of underground water resources will lead to a sharp decline in the water table level and, ultimately, dryness of the wells of the area. The lack of rainfall and the depletion of groundwater will have a number of consequences, including the destruction of vegetation and green space, areas of outstanding beauty and landscape, loss of plant and animal diversity, the destruction of natural ecosystems, reduction of the quality of water resources, soil erosion and an increased flooding potential of the region. In order to prevent or reduce these externalities, a set of actions should be taken by the people and government requiring an abundant capital. To do this, an experiment was designed to investigate the willingness to pay (WTP) for environmental services of the water resources in the region. The experiment consisted of three unique environmental attributes that benefitted from water resources: landscape and beauty (existence of lush and beautiful natural sceneries for the benefit of tourism and the preservation of vegetation), diversity of plant and fauna (plant and animal diversity) and the conservation of soil and water resources (preservation of water quality and quantity, prevention of soil erosion and flooding). These attributes were reviewed on the three levels of the current situation (base level), 50\% restoration (relative improvement) and return to the situation before the externalities (good situation). The benefits constituted three attributes of the four attributes used to evaluate policy choices in CE. Monetary price, as the fifth attribute, to create an income from the benefits of the project, makes the reconstruction of the groundwater resources possible.

In this study, each choice set included three alternatives, wherein one alternative reflected the status quo, while the two other alternatives were opposed to the available alternative that demonstrated an improvement in the environmental attributes. In this method, the respondents were not asked directly to evaluate the reconstruction efforts for the groundwater resources, but rather its consequences. In this project, eight choice sets were used and, with regard to the three alternatives, each respondent was faced with 24 alternatives.

The respondents were asked to choose between the two alternatives in respect of the ground water resources reconstruction. They had the choice not to choose either of the two alternatives and thus maintain the status quo. The exchange was that the respondents would pay for the environmental benefits resulting from the reconstruction of underground water resources, on the top of the annual household water bill. If the respondents chose their current mode, they would then ignore the reconstruction interests and the increase in their water bill would be zero. A sample of the choice set, along with the attributes and their levels, are presented in Table 1. 
Table 1. Example of a choice card

\begin{tabular}{c|c|c|c}
\hline Attribute & Current situation & Option A & Option B \\
\hline Beauty and landscape & $\begin{array}{c}\text { Poor vegetation cover, } \\
\text { deserts without plant } \\
\text { and with pollution }\end{array}$ & $\begin{array}{c}\text { Similar to current } \\
\text { situation }\end{array}$ & $\begin{array}{c}\text { Beautiful landscape } \\
\text { and improving natural } \\
\text { landscape, relative } \\
\text { reduction of pollution }\end{array}$ \\
$\begin{array}{c}\text { Plant and animal } \\
\text { diversity } \\
\text { (biodiversity) }\end{array}$ & $\begin{array}{c}\text { Reduction of plant } \\
\text { diversity and destruction } \\
\text { of plant varieties, } \\
\text { destruction of animals, } \\
\text { reducing the diversity of } \\
\text { wild animals }\end{array}$ & $\begin{array}{c}\text { Similar to current } \\
\text { situation }\end{array}$ & $\begin{array}{c}\text { Increasing plant } \\
\text { diversity }\end{array}$ \\
\hline $\begin{array}{c}\text { Soil and water } \\
\text { resources } \\
\text { conservation }\end{array}$ & $\begin{array}{c}\text { Declining groundwater } \\
\text { table, dry wells, } \\
\text { destruction of vegetation } \\
\text { and consequently soil } \\
\text { erosion and rising flood }\end{array}$ & $\begin{array}{c}\text { relative improvement } \\
\text { and degradation } \\
\text { reduction }\end{array}$ & $\begin{array}{c}\text { Similar to current } \\
\text { situation }\end{array}$ \\
\hline $\begin{array}{c}\text { Price (Monthly } \\
\text { increase in water bill } \\
\text { for any household) }\end{array}$ & $\begin{array}{c}\text { 0 Rials* } \\
\text { (0 USD) }\end{array}$ & $\begin{array}{c}10000 \mathrm{R} \\
(0.33 \text { USD) }\end{array}$ & $\begin{array}{c}\text { 20000 R } \\
\text { (0.66 USD) }\end{array}$ \\
\hline I prefer: & 口 & $\square$ & $\square$ \\
\hline
\end{tabular}

* - Original values were expressed in Rial. USD values have been established using the average exchange rate from the data collection period (October 2015-April 2016): 1 USD = 30132 Rials.

Attributes and their levels in the CE experiment are presented in Table 2.

Table 2. Attributes and attribute levels in the CE experiment

\begin{tabular}{|c|c|c|}
\hline Attributes & Number of Levels & Description of Levels \\
\hline \multirow{3}{*}{ Beauty and landscape } & \multirow{3}{*}{3} & Current situation (bad) \\
\hline & & Situation of relative improvement (good) \\
\hline & & $\begin{array}{l}\text { Situation of the before happening of externality } \\
\text { (very good) }\end{array}$ \\
\hline \multirow{3}{*}{$\begin{array}{l}\text { Plant and animal } \\
\text { diversity }\end{array}$} & \multirow{3}{*}{3} & Current situation (bad) \\
\hline & & Situation of relative improvement (good) \\
\hline & & $\begin{array}{l}\text { Situation of the before happening of externality } \\
\text { (very good) }\end{array}$ \\
\hline \multirow{3}{*}{$\begin{array}{l}\text { Soil and water } \\
\text { resources } \\
\text { conservation }\end{array}$} & \multirow{3}{*}{3} & Current situation (bad) \\
\hline & & Situation of relative improvement (good) \\
\hline & & $\begin{array}{l}\text { Situation of the before happening of externality } \\
\text { (very good) }\end{array}$ \\
\hline Price & 4 & $0,0.33,0.5,0.66 \$(\mathrm{USD})$ \\
\hline
\end{tabular}

The final questionnaire consisted of three parts. The first part covered the respondents' attitude on the conservation of water resources and their impacts on the environment, the second part contained choice sets, while the third part included a number of questions on the demographic characteristics of the respondent. 


\section{Sample size}

Another important part of the study involved determining the study sample size. In the choice experiment method, the number of observations was much greater than the sample size. It is for this reason that there is no specific basis upon which to determine the sample size, and different equations have been developed in many studies (Jafari, 2013). Uremia (1989) suggested the following equation (Eq. 1) to determine the minimum sample size in the choice experiment studies (Jafari, 2013):

$$
N=500 \times \frac{N_{l e v}}{N_{\text {alt }} \times N_{\text {rep }}}
$$

In the above equation, $N_{l e v}$ is the highest number of levels in attribute, $N_{\text {alt }}$ is the number of choices in each choice set, and $N_{\text {rep }}$ is the number of choice sets. According to the presented formula for determining the sample size, 83 samples were determined. However, with the aim of increasing the efficiency, 178 people were interviewed. Due to the lack of responding or incorrect responses, 66 questionnaires were eliminated and eventually 112 questionnaires were used for the analysis.

\section{Model}

The choice experiment (CE) approach has been used in many economic researches, such as transport and marketing researches, and is now becoming increasingly popular for the evaluation of environmental goods and services. The theoretical basis of the CE method is based on the random utility model (Giergiczny and Kronenberg, 2014). The application of this method is theoretically based on Lancaster's characteristics theory of value and it is combined with the random utility theory (Manski, 1977). This method establishes a strong correlation between the random utility approach and environmental and the recreational services demand modeling (Bockstael et al., 1991). The foundation of the model is the indirect utility function.

The assumptions of choice approach are based on the rational behaviors of the individuals, so that their choice is to maximize the utility regarding the limitations of their expenses. The utility of individual $i$ is the function of alternative $j$ choice from choice set $C_{j}$, which is shown in Equation 2 (Hanley et al., 1998):

$$
U_{i j}=V_{i j}\left(Z_{i j}, S_{i}\right)
$$

Choice $j$ is selected in comparison to choice $k$, whereas $U_{i j}>U_{i k}$ is for all $\mathrm{j} \neq \mathrm{k}$. Here, $\mathrm{Z}$ is the environment attribute and the utility of each choice is its function. Individuals' opinions about these attributes may be different; as a result, their socioeconomic characteristics (S) will impact the utility as well. However, as mentioned before, another part of the theoretical basis of choice experiment is the random utility theory. The random utility function of each individual will be as follows (Eq. 3) (Dias and Belcher, 2015; Hanley et al., 1998):

$$
U_{i j}=V_{i j}\left(Z_{i j}, S_{i}\right)+\xi_{i j}\left(Z_{i j}, S_{i}\right)
$$


Now, the probability of choosing choice $j$ to choice $k$ by individual $i$ would be (Eq.4) (Dias and Belcher, 2015):

$$
\operatorname{Pr}_{i}\left(j \mid C_{j}\right)=\operatorname{Pr}\left\{V_{i j}+e_{i j}>V_{i k}+e_{i k}\right\}=\operatorname{Pr}\left\{V_{i j}-V_{i k}>e_{i k}-e_{i j}\right\}, \text { all } j \in c
$$

To estimate the above equation, some assumptions need to be determined for error terms. The common assumption in this case is that the error terms are Independent and Identically Distributed (IID) and have Weibull distribution (34). This indicates that the probability of choice $j$ selection by $i$ is as (Eq. 5) (Hanley et al., 1998):

$$
\operatorname{Pr}_{i}\left(j \mid C_{j}\right)=\frac{\exp \left(\mu V_{i j}\right)}{\sum_{k \in C_{i}} \exp \left(\mu V_{i k}\right)}
$$

Here, parameter $\mu$ is the scale and, since not directly detectable, it is usually assumed to be equal to 1 , which refers to the constant variance error. As $\mu \rightarrow \infty$, the model moves toward becoming deterministic (Hanley et al., 1998). The above model can be estimated in the form of the conditional logit model developed by McFadden (1974), provided that the selections are compatible with the characteristics of the Independence of Irrelevant Alternatives (IIA). The CE dataset can be tested for the feature IIA using the Hausman-McFadden Test. If it is determined that the IIA has been violated, more complex models, such as the nested logit model, should be used.

If $V($.$) is as a linear function V=\beta\left(X_{n}\right)$, where $\mathrm{X}$ is an observable vector of the attributes and $\beta$ is an estimated parameters vector, given two choice alternatives of $j$ and $k$, the model will be as (Eq. 6) (Hanley et al., 1998):

$$
\operatorname{Pr}_{i}\left(j \mid C_{j}\right)=\frac{e^{-\mu \beta^{\prime}\left(x_{i j}-x_{i k}\right)}}{1+e^{-\mu \beta^{\prime}\left(x_{i j}-x_{i k}\right)}}
$$

The log likelihood function will be as follows (Eq. 7):

$$
\ln L=\sum_{i=1}^{N} \sum_{j=1}^{N}\left\{Y_{i j} \cdot \ln \left[\operatorname{Pr}_{i}\left(j \mid C_{j}\right)\right]\right\}
$$

In this function, if respondent $i$ selects alternative $j, Y_{i j}$ will be equal to 1 , otherwise it will be zero. This function can be estimated using Maximum Likelihood. The conditional logit model provides the statistical frameworks of how fluctuation and change in environmental attributes affect the likelihood of choice (Han et al., 2008).

Finally, marginal WTP for each attribute is obtained by dividing the coefficient of each attribute on the price attribute coefficient (Price et al., 2016):

$$
M W T P=-\beta_{i} / \beta_{k}
$$

Where $\beta_{\mathrm{i}}$ is the desired attribute coefficient and $\beta_{\mathrm{k}}$ is the price attribute coefficient. Changes in economic welfare, consistent with the demand theory, can be calculated. 
Hicksian compensating variation, which is called compensating surplus, or economic surplus, is calculated for the case under the study as follows (Kolstad, 2011):

$$
C S=E S=-\frac{1}{b_{y}}\left[\ln \left(\exp \beta^{\prime} x_{i j}^{0}\right)-\ln \left(\exp \beta^{\prime} x_{i j}^{1}\right)\right]
$$

In the above equation, $x_{i j}^{0}$ indicates the initial status utility and $x_{i j}^{1}$ represents an alternative status utility, or the situation after change. Coefficient $b_{y}$ was estimated as the marginal utility of money and price attribute coefficient in the equation. In the conditional logit models, socio-economic variables such as age, sex, educational level, being indigenous, agricultural employment and income were used in addition to the environmental factors.

\section{Results}

As already stated, the number of observations is much larger than the sample size in the choice experiment method; therefore, the estimation has a high efficiency. Given that each questionnaire has eight choice sets and each choice set has three alternatives, each questionnaire has 24 observations which, if multiplied by the sample size (112), the number of observations of this study will be 2,688. Finally, to estimate the model, these observations were analyzed using Stata 14 software.

To specify the conditional logit model, the alternatives within a choice set should follow the independence characteristic of irrelevant alternatives. The Hausman test results show that, by eliminating the status quo, alternative 1 and alternative 2, the null hypothesis for the existence of the independence of the irrelevant alternatives is not rejected. Therefore, in this study, the conditional logit model was used to estimate the model. The results of the conditional logit model estimation are presented in Table 3.

Table 3. Results of conditional logit model

\begin{tabular}{c|c|c|c|c|c}
\hline Variables & Coefficients & Z statistics & $\begin{array}{c}\text { Significance } \\
\text { level }\end{array}$ & $\begin{array}{c}\text { Marginal } \\
\text { effect }\end{array}$ & Symbol \\
\hline $\begin{array}{c}\text { Beauty and } \\
\text { landscape }\end{array}$ & 0.15641 & 2.10 & 0.036 & 0.0340 & $\mathrm{BL}$ \\
\hline $\begin{array}{c}\text { Plant and animal } \\
\text { diversity }\end{array}$ & 0.55873 & 7.55 & 0.000 & 0.1216 & Diver \\
\hline $\begin{array}{c}\text { Soil and water } \\
\text { resources } \\
\text { conservation }\end{array}$ & 0.14562 & 1.86 & 0.062 & 0.0317 & Con \\
\hline Price & -0.000252 & -2.36 & 0.018 & -0.00005 & $\mathrm{Pr}$ \\
\hline Sex & -0.32014 & -1.86 & 0.062 & -0.0692 & $\mathrm{~S}$ \\
\hline Indigenous & -0.77626 & -3.90 & 0.000 & -0.1681 & Ind \\
\hline Education & 0.14840 & 3.80 & 0.000 & 0.0323 & edu \\
\hline $\begin{array}{c}\text { Agricultural } \\
\text { employment } \\
\text { (dummy variable) }\end{array}$ & 1.01742 & 3.64 & 0.000 & 0.2430 & fa \\
\hline Income & $-0.158 \times 10^{-6}$ & -2.07 & 0.039 & $-0.34 \times 10^{-7}$ & In \\
\hline $\begin{array}{c}\text { LR chi2: } 107.58 \\
\text { Prob: } 0.000\end{array}$ & $\begin{array}{c}\text { likelihood: }- \\
912.870\end{array}$ & \multicolumn{3}{|c}{ McFadden pseudo $\mathrm{R}^{2}: 0.06$} \\
\hline
\end{tabular}


The first step in specifying econometric models and their estimation is noting that the sign of estimated coefficients is consistent with economic theory, or that it follows a rational logic. Thereafter, other statistics for the investigation of goodness of fit and other features should be referred to. The coefficients represent the effect of attributes on the probability of choosing the desired alternative. Here, all the coefficients (except the variables, being indigenous and income) had the expected signs. Environmental attributes had a positive sign, which indicates that an improvement in the quality of the environment increased the probability of paying, which itself represents an increase in the individual utility due to the improvement of the environment quality. Price attribute also had a negative sign in accordance with the economic theories. However, the remarkable thing was that, in the studied sample, non-indigenous people were more willing to pay, a fact that is also shown in the model. The reason why this issue is so import is that immigrants came to the region with the aim of generating income and investing here; however, in the event of a water and environment crisis, their investment, particularly in the field of agriculture and related jobs, would be at risk. Another point is that the income coefficient was negative, i.e. those earning less were more willing to pay to preserve water resources and the environment, which was contrary to the theory in appearance. Had this questionnaire been completed simply in tourist places, then it would have been expected that the environment, as a normal or even luxury good, would have had a positive sign. However, the majority of the people in the Orzooiyeh plain are lower than middle class and their main occupation is agriculture, which relies on natural resources and the environment. It seems natural that the reduction of the groundwater levels and dryness of wells and, consequently, the damage to the natural resources and the environment, are causing more concern for these people. In fact, the local people view the natural resources and the environment not as a luxurious commodity, but as capital goods in order to generate income; therefore, the less income they generate, the more this risk is felt and the higher is the WTP to preserve it. Other signs were consistent with the theory. Age variable was not significant, showing that there was little difference in terms of WTP between younger and older individuals.

Given the impossibility of direct interpretation of coefficients in these patterns, marginal rates of substitution were calculated between non-market and monetary attributes. The results of these calculations can be interpreted as ratios of average marginal WTP for a change in each feature, or implicit prices, of each characteristic. These results are shown in Table 4. Based on the results, the highest marginal WTP is for plant and animal diversity, followed by the beauty and landscape, water and soil conservation attributes. As a result of the hot weather and frequent droughts, plant and animal diversity faces more of a risk and it seems natural that the people who live in the region are more concerned about these matters.

Table 4. Marginal WTP of the people in Orzooiyeh (Orzooiyeh plain) for the protection of groundwater and consequently the environment of the area

\begin{tabular}{c|c|c|c|c|c|c}
\hline \multirow{2}{*}{ Attribute } & \multicolumn{2}{|c|}{ Monthly WTP } & \multicolumn{2}{c|}{$\begin{array}{c}\text { Monthly WTP for total } \\
\text { population of region }\end{array}$} & \multicolumn{2}{c}{$\begin{array}{c}\text { annual WTP for total } \\
\text { population of region }\end{array}$} \\
\cline { 2 - 7 } & (Rials) & $\begin{array}{c}\text { USD } \\
\text { equivalent } \\
(\$)\end{array}$ & $\begin{array}{c}\text { (Million } \\
\text { Rials) }\end{array}$ & $\begin{array}{c}\text { USD } \\
\text { equivalent } \\
(\$)\end{array}$ & $\begin{array}{c}\text { (Million } \\
\text { Rials) }\end{array}$ & $\begin{array}{c}\text { USD } \\
\text { equivalent } \\
(\$)\end{array}$ \\
\hline $\begin{array}{c}\text { Beauty and } \\
\text { landscape }\end{array}$ & 6206.75 & 0.21 & 67.65 & 2245.03 & 811.77 & 26940.41 \\
\hline
\end{tabular}




\begin{tabular}{c|c|c|c|c|c|c}
\hline $\begin{array}{c}\text { Plant and animal } \\
\text { diversity }\end{array}$ & 22171.82 & 0.74 & 241.65 & 8019.73 & 2899.81 & 96236.82 \\
\hline $\begin{array}{c}\text { Soil and water } \\
\text { resources } \\
\text { conservation }\end{array}$ & 5778.57 & 0.19 & 62.98 & 2090.16 & 755.77 & 25081.89 \\
\hline $\begin{array}{c}\text { Total WTP for } \\
\text { three attribute }\end{array}$ & 34157.14 & 1.14 & 372.28 & 12354.93 & 4467.34 & 148259.13 \\
\hline
\end{tabular}

According to the General Census of Population and Housing in 2011, the number of Orzooiyeh residents totaled 41,979 people, while the number of households was 10,899 (Statistical Center of Iran, 2015). If the households' WTP (for each environmental attribute, which was damaged) is multiplied by the number of households in the Orzooiyeh, the total monthly amount of money for WTP for each property is obtained, which is presented in the above table. The sum of WTP of all three environmental attributes was equal to $12,354.9$ USD per month; if this number is multiplied by the months of the year, the total annual WTP in the Orzooiyeh region is equal to 148,259.1 USD. According to the results, this figure indicates that, from the perspective of the Orzooiyeh people, environmental attributes of the area have a high monetary value and provide valuable services; however, because of the externalities caused by the excessive withdrawal of groundwater, the region's environment has been damaged. From the perspective of the Orzooiyeh people, their WTP to restore the environment and return it to the state before externalities would be equivalent to 148,259.1 USD.

\section{Discussion}

Although the choice experiment method (from the stated preference methods) is presented as particularly beneficial for valuing non-market goods and services, it is not problem-free. The main problem of the CE method lies in the difficulty it has to connect to different intricate choices or rankings between sets with many attributes and levels. Experimental economists and psychologists have discovered much evidence that there is a restriction to how much information respondents can significantly handle while making a decision (Hanley et al., 2001). Moreover, since respondents are typically presented with a large number of choice sets, both learning and fatigue effects can occur, resulting in obviously illogical choices. Another problem of the CE method, as well as all stated preference techniques, is that the welfare estimates obtained from the $\mathrm{CE}$ method are sensitive to experimental design. For example, the choice of attributes, the levels chosen for them, and the method in which choices are relayed to respondents (e.g. use of photographs versus text descriptions) are not neutral and may affect the values of the estimates of consumers' surplus and marginal utilities (Hanley et al., 2001). In fact, the problem is the CE method's dependency on information quality and information interpretation by researchers and respondents.

A special advantage of using a stated preference method in the Orzooiyeh plain was that it solves problems when accessing spatially explicit environmental data. In fact, data availability is one of the crucial factors that influence the selection of a valuation method (Larson and Perrings, 2013); Therefore, using the CE method is recommended. Another priority of choice experiments is that the approaches avoid direct questions regarding the WTP of respondents, which is often the case in standard contingent 
valuation and is more likely to lead to biased answers (Giergiczny and Kronenberg, 2014). Therefore, in the current study, the CE approach is used.

The WTP for the restoration of groundwater resources in the Orzooiyeh plain of Kerman province increases with the improvement of the situation of groundwater ecosystem services. The respondents' preferences for having restored groundwater resources in the Orzooiyeh plain are heterogeneous due to differences in personal characteristics, such as income, education, agricultural employment, being indigenous and the general views of the local people to natural recourses and the environment. Moreover, three environmental attributes that are dependent on groundwater resources (beauty and landscape, plant and animal diversity, and soil and water resources conservation) have significant WTP. Therefore, this shows that residents can benefit from the environmental attributes of groundwater resources, but have now been deprived from the ecosystem services due to externalities of degradation of water resources. In our study, we requested respondents to make trade-offs between the current situation (with negative externalities), where the water table has fallen dramatically, and two alternatives of the groundwater resources reconstruction by government. This is obviously cognitively demanding a better situation, since the welfare estimates in our study correspond relatively well to the previous results in the other study about environmental attributes of water resources in Iran. The WTP results of the current study and the other study are compared in Table 5.

Table 5. Results comparison of the WTP for ecosystem services

\begin{tabular}{c|c|c}
\hline \multirow{2}{*}{ Attributes } & \multicolumn{2}{|c}{ Monthly WTP (USD) } \\
\cline { 2 - 3 } & $\begin{array}{c}\text { Current study } \\
\text { (study of ground water } \\
\text { resources) }\end{array}$ & $\begin{array}{c}\text { Jafari (2013) } \\
\text { (study of surface water } \\
\text { resources and } \\
\text { damming) }\end{array}$ \\
\hline Beauty and landscape & 0.21 & 0.38 \\
\hline Plant and animal diversity & 0.74 & 0.46 \\
\hline $\begin{array}{c}\text { Soil and water resources } \\
\text { conservation }\end{array}$ & 0.19 & 0.56 \\
\hline Total WTP for three attribute & 1.14 & 1.3 \\
\hline
\end{tabular}

Due to differences between countries, the results of studies in other countries cannot easily be compared with each other. We believe that the respondents were able to make these hypothetical choices. However, future studies should investigate more explicitly the respondents' considerations and other externalities of excessive extraction groundwater, such as water quality, increasing water nitration, salinity, reduction of cultivation area, plant cover and green spaces, reduction of groundwater level, increasing economical cost of agricultural production and social costs, such as migration and unemployment by using other evaluation approaches. The results of the study are not only relevant for increasing the welfare of the existing inhabitants who are affected by optimal groundwater-exploitation planning in agricultural sectors; however, they do contribute by reducing migration and maintaining the economic viability of the region. This information is often an important objective for regional policymakers. 


\section{Conclusion}

The Orzooiyeh plain in Kerman province is a major area for crop production and supplies food staples such as wheat. Agriculture is the main economic activity in this area and most of the local people make a living, either directly or indirectly, from the agricultural sector. Unfortunately, in recent years, due to the excessive withdrawal of groundwater, frequent droughts and lack of groundwater table nutrition, the balance of the plain has been negative and the groundwater level in the region has declined sharply over the last 10 years. The water level decline has brought about a number of economic and environmental externalities. The aim of this study was to investigate the economic and environmental externalities caused by excessive groundwater withdrawal from the Orzooiyeh plain. Given that environmental goods and services have no market in which to be presented, the value of their services should be estimated using non-market methods, such as the choice experiment method. For this purpose, a number of attributes that are currently being severely damaged were examined and evaluated. The Orzooiyeh people's WTP with regard to the improvement of water resources and the environment indicates that improvement of the condition will lead to an increased wellbeing of the citizens. According to the model results, the Orzooiyeh people are willing to pay 148,259.1 USD annually in order to improve and return the environment to how it was before in terms of beauty and landscape, plant and animal diversity, and soil and water resources. In fact, this figure is the price of the externalities or the amount of damages to the environment and natural resources that have reduced the welfare of the people. Based on the results, the Orzooiyeh people view the natural resources and the environment as a capital rather than a commodity; therefore, they are willing to protect their own assets. Most of the people in the region doubted there would be an improvement in the conditions; they believed that the farmers damaged the environment the most and that compensation should be taken from them as a fine for their economic activities. On the other hand, according to the participants of the study, they would have WTP if their payments to revitalize the area are fully invested. Since the value of households' WTP shows their preferences for the improvement of the environment and groundwater resources, it is recommended to receive these amounts by adding them to the monthly water bill of households; this revenue would be used for reforming and restoring the environment and water resources. The amounts collected from the household's WTP could be spent on reforming the irrigation infrastructures or on new water-saving technologies to control, to some extent, the side effects resulting from the excessive withdrawals of groundwater.

Acknowledgement. This study was derived from Ph.D dissertation of first author and supported by Shahid Bahonar University of Kerman. The authors would like to thank the "Kerman Regional Water Authority" (KRWA) for providing some of groundwater data of the Orzooiyeh plain.

\section{REFERENCES}

[1] Bockstael, N., McConnell, K., Strand, I. (1991): Recreation. - In: Braden, J., Klostad, C. (eds.) Measuring the demand for environmental quality, Amsterdam, North-Holland.

[2] Dias, V., Belcher, K. (2015): Value and provision of ecosystem services from prairie wetlands: A choice experiment approach. - Ecosystem Service 15: 35-44.

[3] Dibi, B., Kouame, K.I., Konan-Waidhet, A.B., Savane, I., Biemi, J., Nedeff, V., Lazar, G. (2012): Impact of agriculture on the quality of groundwater resources in peri-urban zone 
of Songon (Cote D'Ivoire). - Environmental Engineering and Management Journal 11: 2175-2184.

[4] Doll, P., Schmied, H.M., Schuh, C., Portmann, F.T., Eicker, A. (2014): Global-scale assessment of groundwater depletion and related groundwater abstractions: combining hydrological modeling with information from well observations and GRACE satellites. Water Resources Research 50(7): 5698-5720.

[5] Eftec/IEEP. (2004): Framework for Environmental Accounts for Agriculture, Final reports, EFTEC, London. - July 2004, Available at: http://unstats.un.org/ unsd/envaccounting/ceea/archive/Framework/Framework_for_EA_forAgriculture.PDF

[6] Environment Agency. (2007): The External Environmental Costs and Benefits of Agriculture in the UK. - Available at: http://www.ibrarian.net/ navon/paper/The_Total_External_Environmental_Costs_and_Benefi.pdf?paperid=75587 59.

[7] Forootan, E., Rietbroeka, R., Kuschea, J., Sharifib, M.A., Awangec, J.L., Schmidtd, M., Omondie, P., Famigliettif, J. (2014): Separation of large scale water storage patterns over Iran using GRACE, altimetry and hydrological data. - Remote Sensing of Environment 140: 580-595.

[8] Gayarti, A., Barbier, E. (2000): Valuating groundwater recharge through agricultural production in the Hadejia-Nguru West land in northern Nigeria. - Agricultural Economics 22: 247-259.

[9] Giergiczny, M., Kronenberg, J. (2014): From Valuation to Governance: Using Choice Experiment to Value Street Trees. - Ambio 43(4): 492-501.

[10] Han, S., Kwak, S.J., Yoo, S.H. (2008): Valuing environmental impacts of large dam construction in Korea: An application of choice experiments. - Environmental Impact Assessment Review 28(1): 256- 266.

[11] Hanley, N., Mourato, S., Wright, R.E. (2001): Choice modeling approaches: a superior alternative for environmental valuation? Journal of Economic Surveys 15(3): 435-462.

[12] Hanley, N., Wright, R.E., Adamowicz, V. (1998): Using Choice Experiments to Value the Environment: Design Issues, Current Experience, and Future Prospects. Environmental and Resource Economics 11(3-4): 413- 428.

[13] Izady, A., Davary, K., Alizadeh, A., Ghahraman, B., Sadeghi, M., Moghaddamnia, A. (2012): Application of "panel-data" modeling to predict groundwater levels in the Neishaboor Plain, Iran. - Hydrogeology Journal 20(3): 435-447.

[14] Jafari, A.M. (2013): The Economics-Environmental Impacts Analysis of the Promotion of the Wall of Ekbatan Dam in Hamedan. - Ph.D thesis, Faculty of agricultural economics and development, Agricultural Economics Department, University of Tehran, Iran.

[15] Joodaki, G., Wahr, J., Swenson, S. (2014): Estimating the human contribution to groundwater depletion in the Middle East, from GRACE data, land surface models, and well observations. - Water Resources Research 50: 2679-2692.

[16] Kaiser, R., Skiller, F. (2003): Options for managing the hidden threat of aquifer depletion in Texas. - Texas Tech Law Review 32: 250-304.

[17] Kerman Regional Water Authority (KRWA). (2014): Report on extension of banning groundwater resources extraction in Orzooiyeh plain. - Ministry of Power, Kerman.

[18] Kolstad, C.D. (2011): Environmental Economics. - (2nd edition). Oxford University Press, New York.

[19] Larson, E.K., Perrings, C. (2013): The value of water-related amenities in an arid city: The case of the Phoenix metropolitan area. - Landscape and Urban Planning 109: 45-55.

[20] Lindgren, A. (1999): The value of water: a study of the Stampriet aquifer in Namibia. Master Thesis, Department of Economics, Umea University, Sweden.

[21] Lv, Y., Gu, S.Z., Guo, D.M. (2010): Valuing environmental externalities from rice-wheat farming in the lower reaches of the Yangtze River. - Ecological Economics 69: 436-1442.

[22] Madani, K. (2014): Water management in Iran: what is causing the looming crisis? Journal of Environmental Studies and Science 4: 315-328. 
[23] Manski, C. (1977): The Structure of Random Utility Models. - Theory and Decision 8(2): 229- 254.

[24] McFadden, D. (1974): Conditional Logit Analysis of Qualitative Choice Behavior. - In: Frontiers of Econometrics, Academic Press, London.

[25] Pretty, J.N., Brett, C., Gee, D., Hine, R.E., Mason, C.F., Morison, J.I.L., Raven, H., Rayment, M.D., Van Der Bijl, G. (2000): An assessment of the total external cost of UK agriculture. - Agricultural Systems 65: 113-136.

[26] Price, J.I., Janmaat, J., Sugden, F., Bharati, L. (2016): Water storage systems and preference heterogeneity in water-scarce environments: A choice experiment in Nepal's Koshi River Basin. - Water Resources and Economics 13: 6-18.

[27] Statistical Center of Iran. (2015): General census of population and housing in 2011. Available at: http://www.amar.org.ir.

[28] TaghiZadeh, S., Soltani, GH. (2013): The impact of groundwater over-extraction on farmers, welfare: The case of wheat producers in Fasa county. - Journal of Agricultural Economics Researches 5(1): 1-22, Available at: http://en.journals.sid.ir/ViewPaper.aspx?ID=363436. (In Persian)

[29] Vega, D.C., Alpizar, F. (2011): Choice Experiments in Environmental Impact Assessment. - The Toro 3 Hydroelectric Project and the Recreo Verde Tourist Center in Costa Rica, Environment for Development Discussion Paper Series, EfD DP, Available at: http://www.efdinitiative.org/sites/default/files/efd-dp-11-04.pdf.

[30] Wei, Y., White, R., Hu, K., Willett, I. (2010): Valuing the environmental externalities of oasis farming in Left Banner, Alxa, China. - Ecological Economics 69: 2151-2157. 